\title{
Maito-Kurikka koulutushanke
}

Matti Ryhänen ${ }^{1)}$, Jyrki Rajakorpi ${ }^{1)}$, Timo Sipiläinen ${ }^{2)}$ ja Tarja Sandvik ${ }^{3)}$

${ }^{1)}$ Seinäjoen ammattikorkeakoulu, SeAMK Ruoka, Ilmajoentie 525, 60800 Ilmajoki, etunimi.sukunimi@seamk.fi

${ }^{2)}$ Helsingin yliopisto, taloustieteen laitos, PL 27, 00014 Helsingin yliopisto, timo.sipilainen@helsinki.fi

${ }^{3)}$ Seinäjoen ammattikorkeakoulu, Etelä-Pohjanmaan maakuntakorkeakoulu, Keskuspuistikko 14, 61300 Kurikka, tarja.sandvik@seamk.fi

Kurikan kaupungissa Etelä-Pohjanmaalla toteutetaan uusimuotoinen koulutushanke Seinäjoen ammattikorkeakoulun, Helsingin yliopiston ja Kurikan maaseutupalveluiden yhteistyönä. Hanke perustuu maitotilayrittäjien, Kurikan maaseutupalveluiden ja sidosryhmien esittämiin toiveisiin. Suurin tarve on kehittää kurikkalaisten maitotilayrittäjien liiketoimintaosaamista. Se on keskeisin osa-alue kilpailukyvyn ja taloudellisen tuloksen parantamisessa. Maitotilaa on osattava johtaa yrityksenä, mikä vaatii kokonaisvaltaista johtamisosaamista.

Maitotilayrittäjä ei voi erilaistaa tuotettaan, koska meijeri tarvitsee prosesseihinsa tasalaatuista maitoa. Maitotilayrittäjän kilpailustrategiaksi jää alhaisten yksikkökustannusten eli kustannusedun tavoittelu. Tällaisessa kilpailutilanteessa keskeistä on järjestää tuotantoprosessi niin, että tavoitetuotos kyetään tuottamaan minimikustannuksin, jolloin voitto maksimoituu. Maitotilayrittäjä voi järjestää kasvi- ja kotieläintuotannon prosessit monella tavoin kuten itse tehden, urakointina, yhteistyönä, verkostoitumalla tai niitä eri lailla yhdistämällä. Maitotilayrittäjäkohtaisesti ratkaistaan, millainen malli kullekin ja/tai kumppaneille sopii parhaiten. Valittavana on esimerkiksi omien resurssien käyttö, yhteiskoneiden hankinta, yhteinen työvoima, osaamisen jakaminen ja yhteisyritysten perustaminen.

Hankkeella autetaan maitotilayrittäjiä kehittymään yritysjohtajina. Uusin tieto tuodaan heidän saatavilleen. Maitotilayrittäjät kehittävät osaamistaan, oppivat hyödyntämään muiden osaamista, jakavat tietoa sekä vertaisoppivat ja hyödyntävät hyviä käytänteitä. Hankkeen tavoitteena on, että maitotilayrittäjät

1) oppivat hyödyntämään alan uusinta tietoa tehokkaasti,

2) oppivat viemään tietoa kannattavasti käytäntöön,

3) omaksuvat hyviä käytänteitä ja

4) muodostavat tarvittaessa yhteistyöverkostoja.

Koulutus tapahtuu työpajoissa ja benchmarkingia hyödyntämällä. Maitotilayrittäjät opiskelevat itsenäisesti ja pienryhmissä. Maitotilayrittäjien omista lähtökohdista annetaan pienryhmissä ohjausta siihen, miten he voivat kehittää yritystoimintaansa sekä parantaa kustannustehokkuutta ja kannattavuutta. Asiantuntijat alustavat työpajoissa, jonka jälkeen pienryhmissä pohditaan uuden tiedon hyödyntämistä käytännön maitotilayrittämisessä. Työskentelyn tulokset puretaan yhdessä. Asiantuntijat ovat tukena ohjaten ja sparraten. He valmentavat, antavat palautetta ja auttavat kehittämistyössä. Maitotilayrittäjät laativat ohjaajien avustamana kehittämissuunnitelmia, joita he toteuttavat käytännössä. Benchmarking-matkoilla verkostoidutaan ja etsitään uusia keinoja maitotilayrityksen toiminnan kehittämiseen.

Asiasanat: maitotilayrittäjä, kilpailukyky, kannattavuus 


\section{Johdanto}

Kurikan kaupungissa Etelä-Pohjanmaalla toteutetaan tutkimuksiin (ks. Närvä ym. 2008, Ryhänen ja Nissinen 2011, Ryhänen ja Laitila 2012, 2014, Sipiläinen ja Ryhänen 2015) pohjautuva uusimuotoinen koulutushanke. Hankeen käynnistäjiä ovat olleet kurikkalaiset maitotilayrittäjät, Kurikan maaseutupalvelu ja heidän sidosryhmänsä. Kurikan kaupungin strategiaan on kirjattu kehittämisohjelman toimenpiteeksi maatalouden kannattavuuden parantaminen. Maaseutupalvelu on ollut yhteydessä maitotilayrittäjiin ja kerännyt heiltä tietoa, millaisia kehittämistarpeita heillä on. Seinäjoen ammattikorkeakoulu ja Helsingin yliopisto ovat suunnitelleet hankkeen yhdessä Kurikan maaseutupalvelun kanssa.

Maitokiintiöiden poistaminen on johtanut tuotannon kasvuun Euroopan unionin alueella, mikä on laskenut maidon hintaa. Myös Venäjän tuontikiellot ovat vaikuttaneet Suomessa maidon hintaan laskevasti. Rakennemuutoksen seurauksena maitotilayritysten määrä vähenee ja yritystoimintaa kehittävät maitotilayrittäjät kasvattavat yritystensä kokoa. Viidesosa eteläpohjalaisista maitotilayrittäjistä on yrittäjäominaisuuksiltaan ja resursseiltaan potentiaalisia yritystoiminnan kehittäjiä (Vehkamäki ym. 2011). Toimintaympäristön muuttuessa maitotilayrittäjien liiketoimintaosaamisen kehittäminen nähtiin tarpeelliseksi. Se koettiin kilpailukyvyn ja taloudellisen tuloksen parantamisessa keskeisimmäksi osa-alueeksi. Hankkeen sisältö on suunniteltu tukemaan tiivistä maantieteellistä aluetta, sillä uudet kustannustehokkaat toimintamallit edellyttävät läheistä yhteyttä toimijoiden kesken.

Uusiin toimintamalleihin voivat kuulua kasvi- ja kotieläintuotannon prosessien järjestäminen uudella tapaa urakointina, yhteistyönä tai verkostomaisesti yrittämällä, mikä mahdollistaa yksikkökustannusten alentamisen ja vapaa-ajan lisäämisen. Kyseeseen voivat tulla esimerkiksi yhteiskoneet, yhteinen työvoima ja yhdessä hankittu osaaminen sekä yhteisyritykset kuten koneasemat peltoviljelyn tarpeisiin tai yhteisnavettayritykset maidontuotantoon. Maitotilayrittäjä voi ulkoistaa hiehonkasvatuksen ja keskittyä ydinliiketoimintaan eli maidontuotantoon. Esimerkkejä toimivista yhteistyömuodoista on jo Etelä-Pohjanmaalla.

Maitotilayrittäjä saa kustannusedun, kun kokonaisprosessin kustannukset maitolitraa kohti ovat pienemmät kuin kilpailijoilla. Meijeri tarvitsee tasalaatuista maitoa prosesseihinsa, joten maitotilayrittäjä ei voi erilaistaa tuotettaan. Meijerin kilpailukeinona on erilaistaminen. Maitotilayrittäjän kilpailustrategiaksi jää siten alhaisten yksikkökustannusten tavoittelu eli kustannusedun haku. Maitotilayrittäjä vaikuttaa kannattavuuteen tuottamalla kustannustehokkaasti. Keskeistä on, että kokonaistuoton ja -kustannusten erotus maksimoidaan.

\section{Tavoitteet}

Hankkeen tavoitteena on auttaa kurikkalaisia maitotilayrittäjiä kokonaisvaltaisessa johtamisessa ja liiketoimintaosaamisen parantamisessa, mikä edesauttaa kilpailukyvyn ja taloudellisen tuloksen parantamisessa. Maitotilayritysten hyvä kannattavuus ja yritystoiminnan kehittäminen näkyvät suoraan Kurikan kaupungin taloudessa ja kylien elinvoimaisuudessa. Maitotilayritysten kehittäminen on tärkeää myös Kurikan kaupungin työllisyydelle. Maidon jatkojalostus on alueella voimakasta. Maidontuotannon merkitys Kurikan kaupungin taloudessa on suurempi kuin maamme kunnissa keskimäärin.

Toimintaympäristön muutos ja kiristynyt kilpailu lisäävät kehittämistoimien tarvetta. Toimintaedellytysten turvaamiseksi tavoitteena on hyödyntää uusia toimintamalleja ja -tapoja, joilla saadaan maitotilayritysten taloudellista tulosta parannettua. Tavoitteena on, että maitotilayrittäjät hyödyntävät alan uusinta tietoa, vievät sitä kannattavasti käytäntöön, omaksuvat hyviä käytänteitä ja muodostavat yhteistyöverkostoja. Oppimisprosessissa hyödynnetään vertaisoppimista ja hyvien käytänteiden omaksumista.

\section{Hankkeen toteutus}

Hanke koostuu kolmesta eri moduulista, jotka kytkeytyvät toisiinsa.

- Moduuli 1. Toimintaympäristö ja maatalousyrityksen resurssit:

o Ulkoisella analyysillä selvitetään yleistä taloudellista kehitystä ja maitoalan kilpailutilannetta, jotta kyetään tunnistamaan oman maitotilayrityksen mahdollisuudet ja uhat. 
Keskeistä on analysoida tulevaisuuden toimintaympäristöä, markkinoita, maatalouspolitiikkaa, kilpailuoloja ja niiden muutoksia. Uusi tieto ja keksinnöt muuttavat maitotilayrittämisen toimintaedellytyksiä. Kuluttajien ruokailutapojen ja -tottumusten, elämäntavan, asenteiden ja sosiaalisen käyttäytymisen muutokset vaikuttavat maitotuotteiden kysyntään, mikä vaikuttaa maitotilayrittäjien toimintaedellytyksiin, tuotantoon ja toimintatapoihin. Maitotilayritysten tehokkuus- ja tuottavuusvaatimukset kasvavat ja kustannusrakenteet muuttuvat. Selvitetään, miten mahdollisuuksia voidaan hyödyntää ja miten uhkilta voidaan suojautua.

o Sisäisellä analyysillä selvitetään maitotilayrityksen sisäistä tilaa eli tekijöitä, joihin maitotilayrittäjä voi omin toimin vaikuttaa. Tällöin tarkastellaan kasvi- ja kotieläintuotannon fyysisiä, taloudellisia ja inhimillisiä resursseja. Maitotilayrittäjä selvittää, miten hän voi välttää, lieventää tai poistaa heikkouksia tai jopa muuttaa niitä vahvuuksiksi sekä miten hän käyttää vahvuuksia hyväksi ja miten hän voi niitä vahvistaa. Analyysin lähtökohta on nykyhetkessä ja siinä, miten maitotilayrittäjä voi toimia tehokkaasti ja kannattavasti. Keskeistä on pohtia, millä resursseilla ja miten niitä hyödyntämällä hän saa kilpailuetua sekä miten hän voi muuttaa yrityksensä sisäisiä heikkouksia vahvuuksiksi.

- Moduuli 2. Tehokkuus ja tuottavuus:

o Tuotos-panossuhteen eli tehokkuuden ja tuottavuuden lisääminen ovat maitotilayrittäjän keskeisimmät keinot kannattavuuden parantamisessa. Tuottavuuden parantaminen liittyy usein teknologisen kehityksen hyödyntämiseen, tehottomuuden vähentämiseen sekä mittakaavaetujen saavuttamiseen. Teknologisen kehityksen hyödyntäminen edellyttää usein yrityskoon kasvattamista, verkostoitumista ja yhteistyötä (vrt. Sipiläinen \& Ryhänen 2015). Työtä korvataan teknologialla. Yritystoimintaa kehittävät maitotilayrittäjät hyödyntävät mm. uutta tuotantotekniikkaa monin tavoin.

- Moduuli 3. Yhteistyö ja verkostoituminen:

o Yhteistyö eri muodoissaan mahdollistaa resurssien käytön tehostamisen, toimintatapojen uudistamisen ja lopulta taloudellisen tuloksen ja kannattavuuden parantamisen. Se mahdollistaa myös vapaa-ajan lisäämisen. Perinteisesti yhteistyötä on tehty tuttujen kesken. Yhteistyöstä vieraiden kesken on saatu myös hyviä kokemuksia. Onnistuneita kokemuksia ja hyväksi havaittuja toimintamalleja kannattaa hyödyntää. Kannustava ote, luotettavan tiedon jako sekä yhteistyön etujen ja haasteiden avoin esille tuonti antavat maitotilayrittäjille uutta pohjaa valintojen tekoon ja yritystoiminnan kehittämiseen. (Ryhänen \& Laitila 2014.)

Oppiminen tapahtuu työpajoissa, benchmarkingilla, tutustumalla vaihtoehtoisiin toimintamalleihin kotimaassa ja ulkomailla, pienryhmätoiminnan avulla sekä itse oppien.

\section{Työpajat}

Työpajoissa jaetaan aihealueesta uutta tietoa asiantuntija-alustuksina, jonka jälkeen maitotilayrittäjät pohtivat pienryhmissä tiedon hyödyntämistä käytännössä. Pienryhmissä keskustellaan ja vaihdetaan kokemuksia. Työpajoissa tuotettu tieto siirretään osallistujien käyttöön. Asiantuntijat sparraavat ja tukevat ryhmien toimintaa.

\section{Bechmarking}

Benchmarking-matkoilla verkostoidutaan ja etsitään uusia keinoja maitotilayrityksen toiminnan kehittämiseen havainnoimalla vaihtoehtoisia tapoja toimia ja hakemalla hyviä käytänteitä. Tutustumiskohteet valitaan siten, että osallistujille jää vahva näkemys siitä, miten asioihin maitotilayrittäjä voi vaikuttaa ja millaisia tuloksia on mahdollista saavuttaa. Osallistujat näkevät, miten kasvin- ja kotieläintuotanto on mahdollista käytännössä järjestää sekä millaisia yhteistyömuotoja ja verkostoja on jo toiminnassa. Tarkoituksena on hakea hyviä käytänteitä ja kannustetaan maitotilayrittäjiä tekemään muutoksia toimintaansa. Samalla pyritään poisoppimaan ajatusmallista "tehdään niin kuin aina on tehty”. Tutustumismatkoja tehdään sekä Etelä-Pohjanmaalle, muualle Suomeen ja Tanskaan. 


\section{Pienryhmätoiminta}

Maitotilayritysten kannattavuus Kurikan kaupungin eri alueilla vaihtelee, sillä niiden toimintaa on kehitetty eri tavoin. Hyviä käytänteitä haetaan benchmarkingilla myös Kurikan sisältä. Benchmarkingin ja työpajojen avulla muodostetaan pienryhmiä. Pienryhmissä maitotilayrittäjät pohtivat ja suunnittelevat omista lähtökohdistaan, miten he voivat parantaa tuottavuutta ja tehokkuutta, lisätä yhteistyötä sekä verkostoitua mm. kasvinviljelijöiden kanssa. Asiantuntijat toimivat tukena ohjaten ja sparraten pienryhmiä. Asiantuntijat antavat palautetta pienryhmille, mikä heidän suunnitelmissaan on hyvää ja mitä tulisi kehittää. He valmentavat ja auttavat kehittämistoimien käytäntöön viennissä. Olemassa olevaa tietoa ja hankkeista saatua uutta tietoa hyödynnetään ohjauksessa. Suunnittelun apuvälineenä käytetään yhteistyön käynnistämisen käsikirjaa (Laitila ym. 2014). Suunnitelmat laaditaan niin, että ne voidaan toteuttaa käytännössä, mikä mahdollistaa kilpailukyvyn ja kannattavuuden parantamisen.

\section{Toteutus}

Kurikan kaupungissa Etelä-Pohjanmaalla toteutetaan tutkimukseen pohjautuva uusimuotoinen koulutushanke Seinäjoen ammattikorkeakoulun, Helsingin yliopiston ja Kurikan maaseutupalvelun yhteistyönä. Maito-Kurikka koulutushanke toteutetaan 1.1.2017-31.12.2018. Hankkeen toteutuksesta vastaa hanketta hallinnoiva Seinäjoen ammattikorkeakoulu, SeAMK Ruoka. Hankkeen toteutuksessa on mukana Helsingin yliopisto. Etelä-Pohjanmaan maakuntakorkeakoulun Kurikan toimipiste vastaa kaikista käytännön järjestelyistä. Rahoittajina ovat Leader Liiveri ja Leader Suupohja Manner-Suomen maaseudun kehittämisohjelmasta 2014-2020. Muut rahoittajat ovat Kurikan kaupunki ja hankkeeseen osallistuvat yrittäjät.

\section{Kirjallisuus}

Laitila, E., Ryhänen, M., Rajakorpi, J., Närvä, M. \& Sipiläinen, T. 2014. Yhteistyön käynnistämisen käsikirja. Seinäjoen ammattikorkeakoulun julkaisusarja A. Tutkimuksia 19: 116-181.

Närvä, M., Ryhänen, M., Veikkola, E., \& Vuorenmaa, T. 2008. Esiselvitys maidontuotannon kehittämiskohteista: loppuraportti. Seinäjoki: Seinäjoen ammattikorkeakoulu. Seinäjoen ammattikorkeakoulun julkaisusarja B. Raportteja ja selvityksiä 36.

Ryhänen, M. \& Nissinen, K. 2011. Kilpailukykyä maidontuotantoon. Toimintaympäristön tarkastelu ja ennakointi. Seinäjoki: Seinäjoen ammattikorkeakoulu. Seinäjoen ammattikorkeakoulun julkaisusarja A. Tutkimuksia 8.

Ryhänen, M. \& Laitila, E. 2012. Yhteistyö ja resurssit maitotiloilla. Verkostomaisen yrittämisen lähtökohtia ja edellytyksiä. Seinäjoki: Seinäjoen ammattikorkeakoulu. Seinäjoen ammattikorkeakoulun julkaisusarja B. Raportteja ja selvityksiä 59.

Ryhänen, M. \& Laitila, E. 2014. Yhteistyö ja verkostosuhteet. Strateginen tarkastelu maidontuotantoon sovellettuna. Seinäjoki: Seinäjoen ammattikorkeakoulu. Seinäjoen ammattikorkeakoulun julkaisusarja A. Tutkimuksia 19. Sipiläinen, T. \& Ryhänen, M. 2015. Tuotannon järjestämisen ja yhteistyön vaikutus tekniseen tehokkuuteen. Yhteistyöllä kilpailukykyä maidontuotantoon -hanke. Helsingin Yliopisto. Taloustieteen laitos. Selvityksiä nro 81. Helsinki 2015. Viitattu 5.12.2017. http://www.helsinki.fi/taloustiede/tutkimus/julkaisut.html\#selv11

Vehkamäki, S., Ylätalo, M., Mäkinen, H., Latva-Kyyny, M. \& Ryhänen, M. 2011. Some entrepreneurial characteristics and resource use on dairy farms in South Ostrobothnia, Finland, in 2003 and 2009. Proceedings of the international scientific conference. Jelgava 2011. Economic science for rural development 24: 114-122. 